\title{
Identification of Risk Factors Cause Cost Overrun at Toll Road Project
}

\begin{abstract}
Asri Nurdiana*, Riza Susanti, and Fardzanela Suwarto
Department of Civil Engineering, School of Vocation, Diponegoro University, Semarang 50275, Indonesia

In Central Java, Indonesia currently has several toll road projects that are also included in the government's national strategic project. This project is a series of Trans Java Toll Road, which connects Java from the West to the East. As a national government strategic project, these projects are a priority. The high demands from the government have an impact on project targets primarily related to costs. Unexpected costs in the project arise in an effort to solve problems. Any change in project cost results cost overrun in the project. The purpose of this study is to identify risk factors that affect the occurrence of cost overrun on toll road projects. This research is restricted to toll road objects in Pantura (national strategy project) that are still in the construction process. The method used in this research is qualitative descriptive method. The data used are secondary data derived from previous research on similar topics.
\end{abstract}

Keywords: Risk at Construction, Cost Overrun, Highway Project.

\section{INTRODUCTION}

One of the challenges in Indonesia's increasing economic growth and improving competitiveness is the improvement of infrastructure. The quality of Indonesia's infrastructure in the 2013-2014 is ranked 82 out of 148 countries. ${ }^{1}$ One of the infrastructure that plays an important role in supporting the economic growth of a country is the road infrastructure. Road plays an important role because it is useful in supporting the smooth of goods transportation and services, and also the road infrastructure serves to connect an area to the others.

Pantura road is one of the national road in Indonesia with length of $1,316 \mathrm{~km}$. This road passes along the north coast of Java and passes through at least 5 (five) provinces in Java Island. Pantura can be said as the main vein of transportation in Indonesia, especially Java because is has high level of significance where the road is traversed by approximately 40,000 to 50,000 vehicles on a daily basis. ${ }^{2}$

There are currently several toll road projects that are included into the government's national strategic project in Central Java. The toll road project is being held to assist the performance of Pantura in accommodating the vehicles.

The obstacles were the high demand and expectation of the government to the projects that included in the national strategy project. The problems in the project plus the high demands from the government have an impact on project targets primarily related to costs. Unexpected costs in the project arise in an effort to solve problems in the project. Any change in the project

*Author to whom correspondence should be addressed. cost will resulted in cost overrun in the project. Cost overrun is a condition in which the actual cost exceeds the planned cost. ${ }^{4}$ The purpose of this study is to identify the risk factors that affect the cost overrun on toll road projects, in this case in Pantura toll road project.

\section{MATERIALS AND METHODS}

The research method was qualitative, means a study that examines the quality of relationships, activities, situations, or various materials. The data used were secondary data obtained from journals and previous studies that used as a guidance to obtain the risk identification of causing cost overrun in toll road projects.

\section{RESULTS AND DISCUSSION}

Risk management is an approach that made toward risk. It was done by identification and analysis of risk. Risk identification is the most important step in project risk management (PRM), as the risk models are constructed based on previously defined risk sources and their interrelations. ${ }^{3}$

In reviewing the cost overrun the risk identification factors, that have the potential impact on project costs, must be known. Cost overrun in the construction phase is highly dependent on the planning, coordination, control of the contractor, and also on the estimatation cost planning. ${ }^{4}$ Based on the literature studies that have been done, the factors of cost overrun in construction project shows as in Table I.

Based on references from previous researches, risks of cost overruns in toll road projects has been identified. In general, 
Table I. Previous studies.

\begin{tabular}{|c|c|c|c|}
\hline No. & Researchers & Title of the study & Factor of cost overrun \\
\hline 1 & $\begin{array}{l}\text { Jesper Kranker Larsen, Geoffrey Qiping } \\
\text { Shen, Søren Munch Lindhard, and } \\
\text { Thomas Ditlev Brunoe }{ }^{5}\end{array}$ & $\begin{array}{l}\text { Factors affecting schedule delay, cost } \\
\text { overrun, and quality level in public } \\
\text { construction projects }\end{array}$ & $\begin{array}{l}\text { Material consultant misjudgment; inconsistency of project } \\
\text { documents; late user change; lack of preliminary } \\
\text { examination before design or tendering; inexperienced } \\
\text { consultant }\end{array}$ \\
\hline 2 & $\begin{array}{l}\text { Garry D. Creedy, Martin Skitmore, and } \\
\text { Johnny K. W. Wong }{ }^{6}\end{array}$ & $\begin{array}{l}\text { Evaluation of risk factors leading to cost } \\
\text { overrun in delivery of highway } \\
\text { construction projects }\end{array}$ & $\begin{array}{l}\text { Changes in the design and scope of work; inadequate } \\
\text { investigation and latent conditions; lack of documentation, } \\
\text { specifications and design; the cost of project management } \\
\text { by the owner; relocation cost; constructability; price } \\
\text { extraction; right-of-way-costs; contractor risk; environment }\end{array}$ \\
\hline 3 & $\begin{array}{l}\text { Aftab Hameed Memon, Ismail Abdul } \\
\text { Rahman, Ade Asmi Abdul Azis }\end{array}$ & $\begin{array}{l}\text { Preliminary study on causative factors } \\
\text { leading to construction cost overrun }\end{array}$ & $\begin{array}{l}\text { Poor design and design delays; unrealistic contract duration } \\
\text { and scope of work; lack of experience; delays in delivery } \\
\text { of materials and equipment; relationship between } \\
\text { management and workers; late preparation and approval } \\
\text { of drawings; inadequate planning and scheduling; site } \\
\text { management and supervision incompetence; errors during } \\
\text { construction; change of specification and material type }\end{array}$ \\
\hline 4 & $\begin{array}{l}\text { Hamed Samarghandi, Seyed Mohammad } \\
\text { Moosavi Tabatabaei, Pouria Taabayan, } \\
\text { Ahmad Mir Hashemi and Keith } \\
\text { Willoughby }\end{array}$ & $\begin{array}{l}\text { Studying the reasons for delay and cost } \\
\text { overrun in construction projects: The } \\
\text { case of Iran }\end{array}$ & $\begin{array}{l}\text { From a contractor's perspective: Inaccuracy of budget } \\
\text { planning and resources; use of low quality materials and } \\
\text { lack of equipment; lack of experienced human resources. } \\
\text { From the consultant's perspective: Less accurate in the FS } \\
\text { review; technical document error; inaccuracy of technical } \\
\text { documents. }\end{array}$ \\
\hline 5 & $\begin{array}{l}\text { Henry Alinaitwe, Ruth Apolot and Dan } \\
\text { Tindiwensi }{ }^{9}\end{array}$ & $\begin{array}{l}\text { Investigation into the causes of delays } \\
\text { and cost overrun in Uganda's public } \\
\text { sector construction projects }\end{array}$ & $\begin{array}{l}\text { Changes in the scope of work; late payment; weak } \\
\text { supervision and control; the high cost of capital; security } \\
\text { and unstable political conditions. }\end{array}$ \\
\hline 6 & $\begin{array}{l}\text { Tonny Sahusilawane, Mohammad Bisri, } \\
\text { Arif Rachmansyah }{ }^{10}\end{array}$ & $\begin{array}{l}\text { Analysis of causes factors cost overrun } \\
\text { on building construction project in } \\
\text { ambon city }\end{array}$ & $\begin{array}{l}\text { The high frequency of implementation changes; too much } \\
\text { repetition of work because of poor quality; Too many } \\
\text { projects are handled at the same time; lack of coordination } \\
\text { between the main contractor and the sub-contractor; lack } \\
\text { of coordination between construction } \\
\text { manager-planner-contractor; disagreements occur within } \\
\text { the project process; the project manager incompetent. }\end{array}$ \\
\hline 7 & $\begin{array}{l}\text { Oko John Ameh, Aliu Adebayo Soyingbe } \\
\text { and Koleola Tunwase Odusami }{ }^{11}\end{array}$ & $\begin{array}{l}\text { Significant factors causing cost overrun in } \\
\text { telecommunication projects in Nigeria }\end{array}$ & $\begin{array}{l}\text { Risk factors include construction, financial condition, cost } \\
\text { estimate, environment }\end{array}$ \\
\hline 8 & $\begin{array}{l}\text { Sameh M. El-Sayegh, Ph.D.; and } \\
\text { Mahmoud H. Mansour }{ }^{12}\end{array}$ & $\begin{array}{l}\text { Risk assessment and allocation in } \\
\text { highway construction }\end{array}$ & $\begin{array}{l}\text { Of the } 33 \text { risks identified in toll road projects in the UAE. The } \\
\text { risk of planning inefficiencies is rated as the greatest risk } \\
\text { to the project. }\end{array}$ \\
\hline
\end{tabular}

Table II. Risk identification.

\begin{tabular}{|c|c|}
\hline Identification of risk & References \\
\hline \multicolumn{2}{|l|}{ Internal } \\
\hline Poor design & Creedy et al., ${ }^{6}$ Memon et al., ${ }^{7}$ El-Sayegh et al., ${ }^{12}$ Samarghandi et al. ${ }^{8}$ \\
\hline Frequent design/scope of change & Creedy et al., ${ }^{6}$ Memon et al., ${ }^{7}$ Samarghandi et al., ${ }^{8}$ Alinaitwe et al. ${ }^{9}$ Ameh et al. ${ }^{11}$ \\
\hline Inexperienced or newly qualified consultant & Memon et al. ${ }^{7}$ \\
\hline Inexperienced or newly qualified contractor & Larsen et al., ${ }^{5}$ Memon et al., ${ }^{7}$ Samarghandi et al., ${ }^{8}$ Ameh et al. ${ }^{11}$ \\
\hline Delays in reviewing and approving design by client & Memon et al. ${ }^{7}$ \\
\hline Mistake in technical documents & Memon et al., ${ }^{7}$ Samarghandi et al. ${ }^{8}$ \\
\hline Inadequate labour availability & Alinaitwe et al., ${ }^{9}$ Ameh et al. ${ }^{11}$ \\
\hline Low productivity of labour & Memon et al., ${ }^{7}$ Samarghandi et al. ${ }^{8}$ \\
\hline Fluctuations in the price of materials & Creedy et al., ${ }^{6}$ Memon et al., ${ }^{7}$ Ameh et al. ${ }^{11}$ \\
\hline Adherence of outdate construction method & El-Sayegh et al., ${ }^{12}$ Samarghandi et al. ${ }^{8}$ \\
\hline Rework & Memon et al., ${ }^{7}$ Alinaitwe et al. ${ }^{9}$ \\
\hline Poor monitoring & Alinaitwe et al. ${ }^{9}$ \\
\hline \multicolumn{2}{|l|}{ Eksternal } \\
\hline Subcontractor's performance & Memon et al. ${ }^{7}$ \\
\hline Unforseen soil conditions & Lee (2008), El-Sayegh et al. ${ }^{12}$ \\
\hline Government policies (law and regulation) & Ameh et al. ${ }^{11}$ \\
\hline Project location & Creedy et al., ${ }^{6}$ Alinaitwe et al.,${ }^{9}$ Ameh et al. ${ }^{11}$ \\
\hline High inflation and interest rate & Samarghandi et al., ${ }^{8}$ Alinaitwe et al. ${ }^{9}$ \\
\hline Bad weather & Creedy et al., ${ }^{6}$ Memon et al., ${ }^{7}$ El-Sayegh et al., ${ }^{12}$ Samarghandi et al., ${ }^{8}$ Ameh et al. ${ }^{11}$ \\
\hline Long period between design and time of tendering & Ameh et al. ${ }^{11}$ \\
\hline Supplier's manipulation & Ameh et al. ${ }^{11}$ \\
\hline Duration of contract period & Ameh et al. ${ }^{11}$ \\
\hline
\end{tabular}


this risk identification consists of 2 groups, internal and external factors. The identification of these risks is presented in Table II.

Risk identification that causing cost overrun on toll roads based on study literature are 21 risks that divided into 12 internal risks and 9 external risks. The identification of these risks can be used as reference in toll road projects to develop risk management concepts in forecasting cost overruns in the project.

\section{CONCLUSION}

The conclusion from this research based on the study literature that has been done is that the cause of the cost overrun in toll road project consists of 21 risks, where many risks arising from internal factors. For further research, it can be analyzed the risk and risk response that is expected to reduce the probability of potential cost overrun in toll road projects.

\section{References and Notes}

1. Simanjutak, Dinas Pekerjaan Umum: Jakarta (2014)

2. Anonim, Rencana Strategis 2010-2014 (2010).

3. O. Gulbin and D. Irem, International Journal of Project Organisation and Management 3 (2011)

4. Y. Dapu and W. R. Dundu, Jurnal Sipil Statik 4, 641 (2016)

5. J. K. Larsen, S. M. Lindhard, G. Q. Shen, and T. D. Brunoe, Journal of Management in Engineering 32 (2016).

6. G. D. Creedy, M. Skitmore, and J. K. W. Wong, Journal of Construction Engineering and Management 136, 528 (2010).

7. A. H. Memon, I. A. Rahman, and A. A. A. Azis, International Journal of Sustainable Construction Engineering and Technology 2, 57 (2011).

8. H. Samarghandi, S. Mohammad, M. Tabatabaei, A. Mirhashemi, and K. Willoughby, Journal of Construction in Developing Countries, Early View 51 (2016).

9. H. Alinaitwe, R. Apolot, and D. Tindiwensi, Journal of Construction in Developing Countries 18, 33 (2013).

10. Sahusilawane Tony and A. R. Mohammad Bisri, Analisis Faktor-Faktor Penyebab Terjadinya Pembengkakan Biaya (Cost Overrun) 5, 118 (2011).

11. O. J. Ameh, A. A. Soyingbe, and K. T. Odusami, Journal of Construction in Developing Countries 15, 49 (2010).

12. S. M. El-Sayegh and M. H. Mansour, Journal of Management in Engineering 31 (2015).

Received: 13 September 2017. Accepted: 23 September 2017. 